\title{
Production and upregulation of granulocyte chemotactic protein-2/CXCL6 by IL-I $\beta$ and hypoxia in small cell lung cancer
}

\author{
YM Zhu',', SM Bagstaff' and PJ Woll' \\ 'Department of Clinical Oncology, Division of Genomic Medicine, School of Medicine and Biomedical Sciences, Institute for Cancer Studies, University of \\ Sheffield, Beech Hill Road, Sheffield SIO 2RX, UK
}

Small cell lung cancer (SCLC) is characterised by early and widespread metastasis. However, SCLC cells have so far been found to produce low levels of known pro-angiogenic factors. We speculated that SCLC cells might produce alternative pro-angiogenic factors. Here, we report that a panel of SCLC cell lines constitutively secrete granulocyte chemotactic protein-2 (GCP-2)/CXCL6, a CXC ELR + chemokine. In contrast, none of the three tested NSCLC cell lines secreted GCP-2. Production of GCP-2 in vivo was also confirmed in seven out of nine specimens with SCLC. We demonstrate that expression of GCP-2 is mediated by NF- $\kappa$ B as ALLN, an NF- $\kappa$ B pathway inhibitor, almost completely abolished GCP-2 production in SCLC cell lines. We also demonstrate that GCP-2 can be significantly upregulated by IL- I $\beta$ and hypoxia in SCLC cell lines. This result suggests a role for GCP-2 in promoting tumour progression in vivo under unfavourable conditions such as oxygen deprivation. As SCLC cells express both GCP-2 and its receptors CXCRI and CXCR2, their biological significance in SCLC progression was further studied. We demonstrate that GCP-2 is an autocrine growth factor. Cell proliferation was significantly inhibited by anti-GCP-2 neutralising antibody in two high-GCP-2producing cell lines. In addition, expression of the proliferation marker PCNA was upregulated by exogenous GCP-2 in two lowGCP-2-producing cell lines. Taken together, these results suggest an important role for GCP-2 as an autocrine mitogen in the growth and metastasis of SCLC.

British Journal of Cancer (2006) 94, 1936-1941. doi:I0.1038/sj.bjc.6603177 www.bjcancer.com

Published online 23 May 2006

(c) 2006 Cancer Research UK

Keywords: GCP-2; CXCL6; CXCRI; CXCR2; metastasis; lung cancer

Lung cancer is the leading cause of cancer-related deaths worldwide. Small cell lung cancer (SCLC), which has a neuroendocrine phenotype, is characterised by early and widespread metastasis. Despite initial chemosensitivity, resistant relapse is common, and the poor prognosis has not improved in the past 20 years. The establishment of distant metastases, a process that is pathognomic of cancer, depends on angiogenesis. Limited data are available on the contribution of different angiogenic factors to SCLC metastasis.

There is increasing evidence that chemotactic cytokines (chemokines) and their receptors play key roles in cancer progression and metastasis (Balkwill, 2004; Zlotnik, 2004). Many angiogenic factors such as vascular endothelial growth factor (VEGF), basic fibroblast growth factor (bFGF), platelet-derived endothelial cell growth factor (PD-ECGF) and CXC chemokines are associated with tumour progression and metastasis of lung cancer (Cox et al, 2000). Among CXC chemokines, those with a conserved Glu-Leu-Arg (ELR +$)$ N-terminal motif are pro-angiogenic, whereas ELR - chemokines inhibit angiogenesis (Strieter et al, 1995). The ELR + CXC chemokines include interleukin-8 (IL-8), growth-related oncogenes- $\alpha,-\beta$, and $-\gamma$, granulocyte chemotactic

*Correspondence: Dr YM Zhu; E-mail: y.m.zhu@sheffield.ac.uk Received 24 January 2006; revised 24 April 2006; accepted 25 April 2006; published online 23 May 2006 protein 2 (GCP-2) and epithelial neutrophil-activating protein-78 (ENA-78). The effects of ELR + CXC chemokines are mediated through binding to CXCR1 and CXCR2 receptors. All the ELR + CXC chemokines utilise the CXCR2 receptor, but only IL- 8 and GCP-2 recognise the CXCR1 receptor, which we found to be the predominant receptor in lung cancer cells (Zhu et al, 2004). Overexpression of IL-8 has been detected in non-small cell lung cancer (NSCLC), where its expression correlates with tumorigenic and metastatic potential (Yuan et al, 2000; Chen et al, 2003). We have previously studied the expression of IL- 8 and its receptors in a panel of NSCLC and SCLC cell lines. We found that whereas NSCLC produced high levels of IL-8, SCLC produced low levels of IL-8. However, SCLC expressed higher levels of the IL-8 receptors, CXCR1 and CXCR2 than NSCLC (Zhu et al, 2004). The only other known ligand for CXCR1 receptor is GCP-2. This led us to examine whether SCLC produces GCP-2.

Granulocyte chemotactic protein-2 was cloned as a neutrophil chemoattractant (Proost et al, 1993). Like other CXC ELR + chemokines, GCP-2 was demonstrated to promote tumour growth through its angiogenic effects in animal models (Strieter et al, 1995; Van Coillie et al, 2001). Recently, Gijsbers et al (2005) reported that endothelial cells within gastrointestinal tumours produced GCP-2 that was mitogenic to the endothelial cells and motogenic to the endothelial cells and neutrophils. These results confirmed that GCP-2 could play an important role in human 
tumour angiogenesis. Here, we show that GCP-2 is constitutively secreted in a panel of SCLC cell lines and in clinical SCLC specimens but not in NSCLC cell lines. We have investigated the regulation of GCP-2 production and its biological functions in SCLC.

\section{MATERIALS AND METHODS}

\section{Lung cancer cell lines and reagents}

The SCLC cell lines used were GLC-19, H69, H345, H711 and Lu165. The NSCLC cell lines used were A549, H460 and MOR/P. All cell lines were cultured in RPMI 1640 (BioWhittaker, Verviers, Belgium) and $10 \%$ heat-inactivated FBS (QB perbio, Tattenhall, Cheshire, UK) in humidified $5 \% \mathrm{CO}_{2}, 95 \%$ air at $37^{\circ} \mathrm{C}$. For hypoxic experiments, the cells were incubated in a humidified Heto multigas incubator in $0.5 \% \mathrm{O}_{2}, 5 \% \mathrm{CO}_{2}$ and $95 \% \mathrm{~N}_{2}$. ALLN (Calpain Inhibitor; MG101) was purchased from Calbiochem (Nottingham, UK). Mouse anti-human GCP-2, CXCR1 and CXCR2, and rGCP-2 were purchased from R\&D systems (Abingdon, UK). The rabbit anti-human NF- $\kappa \mathrm{B}$ (p65) antibody or rabbit antihuman phosphorylated NF- $\kappa \mathrm{B}$ (pp65) antibody were purchased from Cell Signaling Technology (Beverly, MA, USA).

\section{Reverse transcription-polymerase chain reaction (RT - PCR)}

Total RNA was isolated by using the RNeasy mini kit (Qiagen, West Sussex, UK) following the manufacturer's protocol. The expression of mRNA for GCP-2 and GAPDH was determined by RT - PCR as described previously (Zhu et al, 2003). The primers for GCP-2 are as follows: sense, $5^{\prime}$-CGC TGG TCC TGT CTC TGC T-3'; antisense, $5^{\prime}$-GTT TTT CTT GTT TCC ACT GTC C-3'. The primers for GAPDH are as follows: sense, $5^{\prime}$-CCA CCC ATG GCA AAT TCC ATG GCA-3'; antisense, 5'-TCT AGA CGG CAG GTC AGG TCC ACC- $3^{\prime}$. Amplification was carried out in a Biometra thermal cycler after an initial denaturation at $94^{\circ} \mathrm{C}$ for $3 \mathrm{~min}$. This was followed by 35 cycles of PCR using the following temperature and time profile: denaturation at $94^{\circ} \mathrm{C}$ for $40 \mathrm{~s}$, primer annealing at $58^{\circ} \mathrm{C}$ for $40 \mathrm{~s}$, primer extension at $72^{\circ} \mathrm{C}$ for $1 \mathrm{~min}$, and a final extension of $72^{\circ} \mathrm{C}$ for $6 \mathrm{~min}$. The PCR products (235 bp for GCP-2 and $593 \mathrm{bp}$ for GAPDH) were visualized by electrophoresis on a $1.5 \%$ agarose gel in $0.5 \times$ TBE buffer (44.5 mM Tris borate, $1 \mathrm{~mm}$ EDTA, pH 8.3) after staining with $0.5 \mu \mathrm{g} \mathrm{ml}^{-1}$ ethidium bromide.

\section{Enzyme-linked immunosorbent assay (ELISA)}

Granulocyte chemotactic protein-2 concentrations in the culture media were determined by ELISA (R\&D systems, Abingdon, UK) as previously described for IL-8 (Zhu et al, 2003; Zhu et al, 2004). The concentration of GCP-2 was determined by measuring the optical density (OD) at $450 \mathrm{~nm}$ in a Dynatech MR5000 microplate reader.

\section{Flow cytometry analysis of cell surface expression of CXCR1 and CXCR2}

The cells were washed twice with phosphate-buffered saline (PBS) and then suspended in $100 \mu \mathrm{l}$ of FACS buffer ( $2 \%$ bovine serum albumin, $2 \%$ normal rabbit serum in PBS), and then $2 \mu \mathrm{g}$ of mouse anti-human monoclonal anti-CXCR1 or anti-CXCR2 antibody or IgG control antibody ( $R \& D$ systems) were added and incubated for $40 \mathrm{~min}$ on ice. After washing twice with PBS, the cells were suspended in $100 \mu \mathrm{l}$ of FACS buffer plus 1:20 diluted fluorescein isothiocyanate (FITC)-conjugated rabbit anti-mouse IgG (DakoCytomation, Ely, UK) and incubated for $30 \mathrm{~min}$ on ice. The cells were washed twice with PBS and fixed in $100 \mu$ l of FACS buffer containing $1 \%$ paraformaldehyde. The cells were analysed on a FACSort flow cytometer (Becton Dickinson, San Jose, CA, USA).

\section{Western blotting and immunofluorescences}

For NF- $\kappa$ B p65 and pp65 detection, nuclear and cytoplasmic extracts were prepared as follows: cells were first lysed in $10 \mathrm{~mm}$ Tris-HCl ( $\mathrm{pH} 7.9$ ), $60 \mathrm{~mm} \mathrm{KCl,} 1 \mathrm{~mm}$ EDTA, $1 \mathrm{~mm}$ DTT, $1 \mathrm{~mm}$ Pefabloc, $50 \mu \mathrm{g} \mathrm{ml}^{-1}$ antipain, $100 \mu \mathrm{g} \mathrm{ml}^{-1}$ chymostatin, $1 \mu \mathrm{g} \mathrm{ml}^{-1}$ leupeptin, $1 \mu \mathrm{g} \mathrm{ml}^{-1}$ pepstatin, $40 \mu \mathrm{g} \mathrm{ml}^{-1}$ bestatin, $3 \mu \mathrm{g} \mathrm{ml}^{-1} \mathrm{E}-64$ and $0.1 \%$ NP-40. The cytoplasmic fraction was removed and the pellet resuspended in $20 \mathrm{~mm}$ Tris- $\mathrm{HCl}(\mathrm{pH} \mathrm{8.0)}, 400 \mathrm{~mm} \mathrm{NaCl}$, $1.5 \mathrm{~mm} \mathrm{MgCl}, 1.5 \mathrm{~mm}$ EDTA, $1 \mathrm{~mm}$ DTT, $25 \%$ glycerol, $1 \mathrm{~mm}$ Pefabloc, $50 \mu \mathrm{g} \mathrm{ml}^{-1}$ antipain, $100 \mu \mathrm{g} \mathrm{ml}^{-1}$ chymostatin, $1 \mu \mathrm{g} \mathrm{ml}^{-1}$ leupeptin, $1 \mu \mathrm{g} \mathrm{ml}^{-1}$, pepstatin, $40 \mu \mathrm{g} \mathrm{ml}^{-1}$ bestatin and $3 \mu \mathrm{g} \mathrm{ml}^{-1}$ E-64. The nuclear fraction was removed. For GCP-2 detection, cells were lysed in Cellytic ${ }^{\mathrm{TM}}$ Mammalian cell lysis extraction buffer (Sigma, Poole, Dorset, England). The protein concentration was determined by the Bradford assay. A measure of $20 \mu \mathrm{g}$ of protein was used per lane. The detailed procedure from gel eletrophoresis to detection was described previously (Zhu et al, 2003). Expression of NF- $\kappa \mathrm{B}$ p65 was also detected by immunofluorescence as described by Zhu et al (2003). Briefly, SCLC cells were fixed in $4 \%$ paraformaldehyde in PBS, permeabilized with $0.2 \%$ Triton X100. Each slide was incubated with blocking solution (1.5\% goat serum in PBS), then with diluted rabbit anti-human NF- $\kappa \mathrm{B}(1: 200$ dilution) antibody, and finally with $1: 160$ diluted FITC-conjugated goat anti-rabbit secondary antibody. The slides were then mounted onto slides with Vectashield mounting medium (Vector Laboratories, Inc., Burlingam, CA, USA). Fluorescence was observed and photographed using a Zeiss microscope.

\section{MTT assay}

Cell proliferation was measured by 3-(4,5-dimethylthiazol-2-yl)2,5-diphenyltetrazolium bromide (MTT) assay (Sigma, Dorset, England). A total of $5 \times 10^{3}$ cells were seeded into 96-well flatbottomed plates in triplicate in $100 \mu \mathrm{l}$ RPMI containing $0.5 \%$ FCS. After overnight culture, cells were treated with various concentrations of monoclonal anti-GCP-2 antibody or control antibody mouse IgG for 24 and $48 \mathrm{~h}$. A volume of $10 \mu \mathrm{l}$ of MTT $\left(5 \mathrm{mg} \mathrm{ml}^{-1}\right)$ was added to each well $4 \mathrm{~h}$ before the end of experiments. MTT solvent $(100 \mu \mathrm{l}$ of $0.1 \mathrm{~N} \mathrm{Hcl}$ in anhydrous isopropanol) was added and absorbance of the converted dye was measured at a wavelength of $570 \mathrm{~nm}$. The background was also measured at $690 \mathrm{~nm}$.

\section{Statistical analysis}

All results are expressed as mean \pm s.e.m. The unpaired Student's $t$-test was used to evaluate the significance of differences between groups, accepting $P<0.05$ as the level of significance.

\section{RESULTS}

Release of granulocyte chemotactic protein-2 from small cell lung cancer but not from non-small cell lung cancer

Granulocyte chemotactic protein-2 protein was measured in conditioned serum-free medium of a panel of SCLC and NSCLC cell lines by ELISA. Constitutive release of GCP-2 was found in all five SCLC cell lines but in none of the three NSCLC cell lines (Figure 1A). After $24 \mathrm{~h}$, the concentration of GCP-2 in the SCLCconditioned medium was $1080 \pm 72 \mathrm{pg} \mathrm{ml}^{-1} / 2 \times 10^{6}$ cells in $\mathrm{H} 711$, $907 \pm 40 \mathrm{pg} \mathrm{ml}^{-1} / 2 \times 10^{6}$ cells in $\mathrm{H} 345, \quad 377 \pm 24 \mathrm{pg} \mathrm{ml}^{-1} / 2 \times 10^{6}$ cells in H69, $346 \pm 31 \mathrm{pg} \mathrm{ml}^{-1} / 2 \times 10^{6}$ cells in GLC-19 and $216 \pm 30 \mathrm{pg} \mathrm{ml}^{-1} / 2 \times 10^{6}$ cells in Lu165. GCP-2 was also detected in cell lysates by Western blotting (Figure 1A) although low levels 

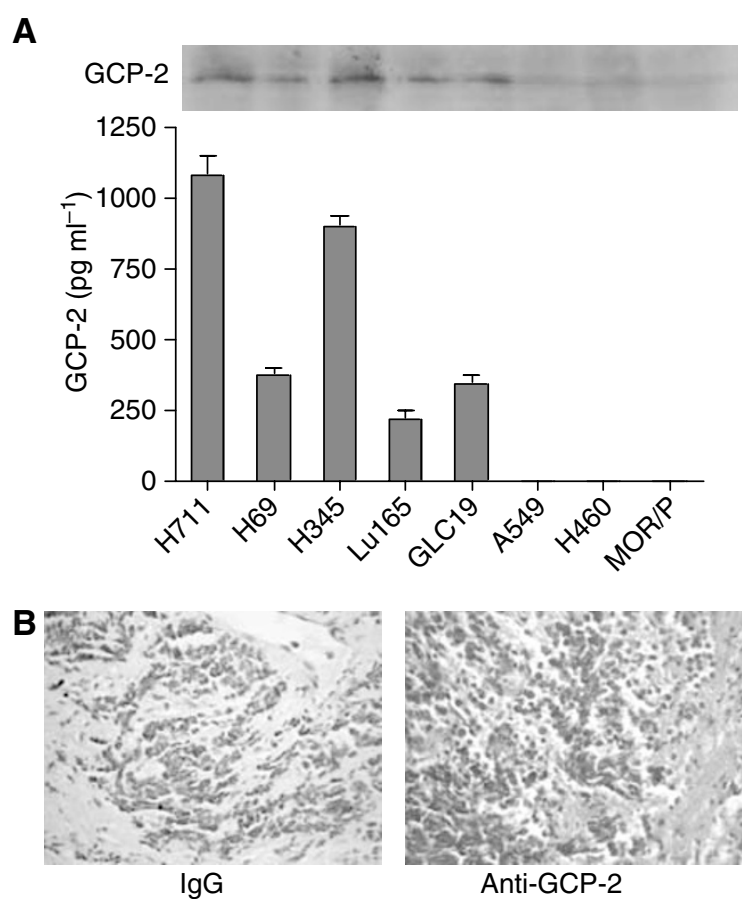

Figure I Expression and release of GCP-2 from SCLC cells but not from NSCLC cells. (A) GCP-2 protein was measured by ELISA in $24 \mathrm{~h}$ conditioned serum-free medium of a panel of SCLC and NSCLC cell lines. Constitutive release of GCP-2 was found in all the five SCLC cell lines but in none of the three NSCLC cell lines. GCP-2 was also detected in cell lysates from SCLC but not from NSCLC cell lines by Western Blotting. Each bar is the mean \pm s.e.m. of three determinations from three indepedent experiments. (B) Production of GCP-2 in vivo was confirmed by immunohistochemistry on biopsy samples in seven out of nine patients (78\%).

were found in cell lysates by ELISA (data not shown), suggesting that GCP-2 is released from cells soon after synthesis. The production of GCP-2 in vivo was confirmed by immunohistochemistry on biopsy samples from nine SCLC patients (Figure 1B). GCP-2 was positive in seven out of nine patients (78\%).

\section{Constitutive expression of granulocyte chemotactic protein- 2 is abolished by targeting NF- $\kappa B$}

The $5^{\prime}$ flanking region of GCP-2 has been cloned and binding sites for three major transcription factors identified there: nuclear factor (NF)- $\kappa \mathrm{B}$, NF-IL-6 and activating protein (AP)-2 (Rovai et al, 1997). We investigated the role of NF- $\kappa \mathrm{B}$ in regulating GCP-2 activity in SCLC cell lines. Using antibodies specific for total NF$\kappa \mathrm{B}$ p65 and phosphorylated p65, we studied the cellular distribution of phosphorylated and unphosphorylated p65 (Figure 2A). p65 was found in both the nuclear and cytoplasmic cell fractions but phosphorylated p65 was located only in the nucleus. To test whether NF- $\kappa \mathrm{B}$ regulated GCP-2 expression, the NF- $\kappa \mathrm{B}$ signal pathway was targeted in two high-GCP-2-producing cell lines: H711 and H345. ALLN, which prevents $\mathrm{I} \kappa \mathrm{B}$ degradation and hence inhibits nuclear translocation of NF- $\kappa \mathrm{B}$ (Figure $2 \mathrm{C}$ ), significantly reduced GCP-2 release in a dose-dependent fashion in both H711 and $\mathrm{H} 345$ cells (Figure 2B). GCP-2 was reduced to $355 \pm 44 \mathrm{pg} \mathrm{ml}^{-1}$ (67\% reduction, $P<0.01$ ) at a final concentration of $10 \mu \mathrm{M}$ of ALLN and further reduced to $83 \pm 4 \mathrm{pg} \mathrm{ml}^{-1}(92 \%$ reduction, $P<0.001)$ at $50 \mu \mathrm{M}$ of ALLN from $1078 \pm 26 \mathrm{pg} \mathrm{m}^{-1}$ at control in H711. GCP-2 was reduced to $71 \pm 8 \mathrm{pg} \mathrm{ml}^{-1}(91 \%$ reduction, $P<0.001)$ at $10 \mu \mathrm{M}$ of ALLN and further reduced to $41 \pm 3 \mathrm{pg} \mathrm{ml}^{-1}$ (95\% reduction, $P<0.001)$ at $50 \mu \mathrm{M}$ of ALLN from $815 \pm 25 \mathrm{pg} \mathrm{ml}^{-1}$ at control in
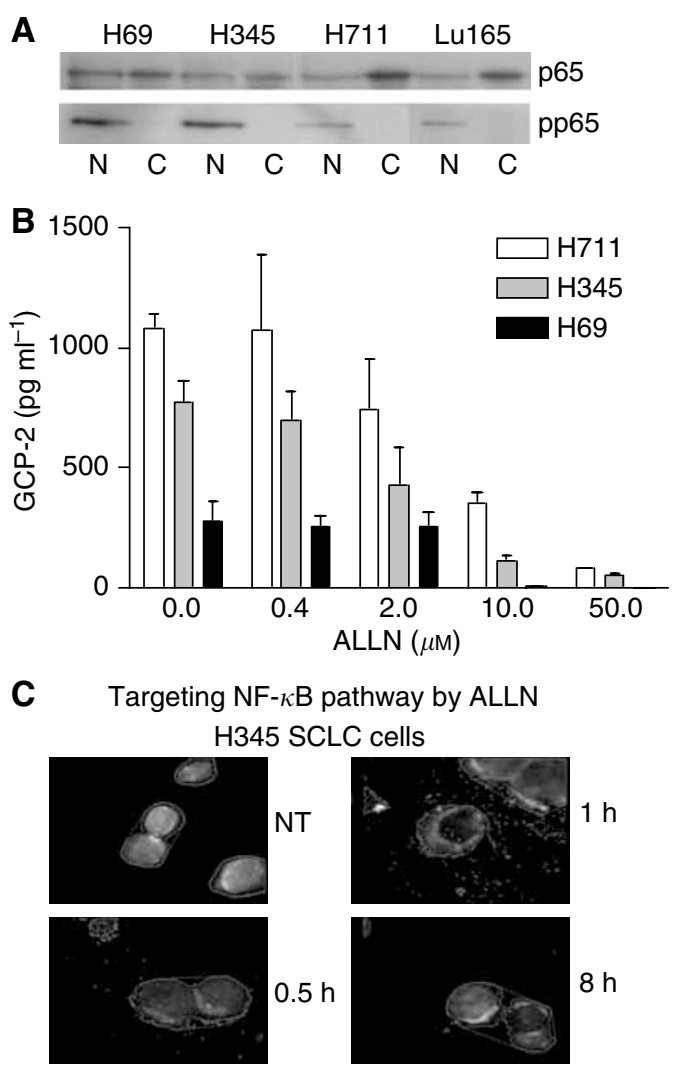

Figure 2 Constitutive expression of GCP-2 in SCLC cells is mediated by NF- $\kappa$ B. (A) Expression of NF- $\kappa$ B p 65 was detected by Western blotting in both cytoplasmic (C) and nuclear (N) fractions in SCLC cell lines. In contrast, phosphorylated p65 (pp65) was only detected in nuclear fractions in those cells. (B) ALLN significantly reduced GCP-2 release, measured by ELISA, in a dose-dependent fashion in H7II, H345 and H69 cells. GCP-2 was reduced at least $80 \%$ when cells were treated at a final concentration of 10 and $50 \mu \mathrm{M}$ of ALLN in all SCLC cell lines tested. Each bar is the mean \pm s.e.m. of three determinations from two independent experiments. (C) Nuclear p65, detected by immunofluorescence, was reduced following treatment with ALLN at a final concentration of $10 \mu \mathrm{M}$ in $\mathrm{H} 345$ cells.

H345. Granulocyte chemotactic protein-2 was also reduced to less than $11 \pm 1 \mathrm{pg} \mathrm{ml}^{-1}$ at $10 \mu \mathrm{M}$ of ALLN from $277 \pm 34 \mathrm{pg} \mathrm{ml}^{-1}$ in H69 (96\% reduction, $P<0.001$ ).

\section{Regulation of granulocyte chemotactic protein-2 secretion by IL-1 $\beta$}

IL- $1 \beta$ has been shown to be the predominant inducer of GCP-2 in non-tumour cells such as mesenchymal cells (Wuyts et al, 2003) and endometrial stromal cells (Mine et al, 2003). To assess whether IL- $1 \beta$ induces GCP- 2 in SCLC cell lines, the high-GCP-2-producing $\mathrm{H} 345$ and $\mathrm{H} 711$ cells were treated by rIL-1 $\beta$ at a final concentration of 0.1 or $1 \mathrm{ng} \mathrm{ml}^{-1}$ for $24 \mathrm{~h}$ (Figure $3 \mathrm{~A}$ ). A significant increase in GCP-2 release was found at $0.1 \mathrm{ng} \mathrm{ml}^{-1}$ in both $\mathrm{H} 345(84 \%$ increase, $P<0.01)$ and H711 (53\% increase, $P<0.01)$ cell lines. No further increase of GCP-2 was found when IL- $1 \beta$ was increased to $1 \mathrm{ng} \mathrm{ml}^{-1}$ (Figure $3 \mathrm{~A}$ ). As shown by RT-PCR, IL-1 $\beta$ upregulated GCP-2 mRNA in both cell lines, indicating that the upregulation is mediated by increased transcription of GCP-2 (Figure 3B).

\section{Upregulation of GCP-2 by hypoxia}

To test whether hypoxia upregulates GCP-2, H711 cells were cultured under normoxia and hypoxia $\left(0.5 \% \mathrm{O}_{2}\right)$ for 24,48 and 
A
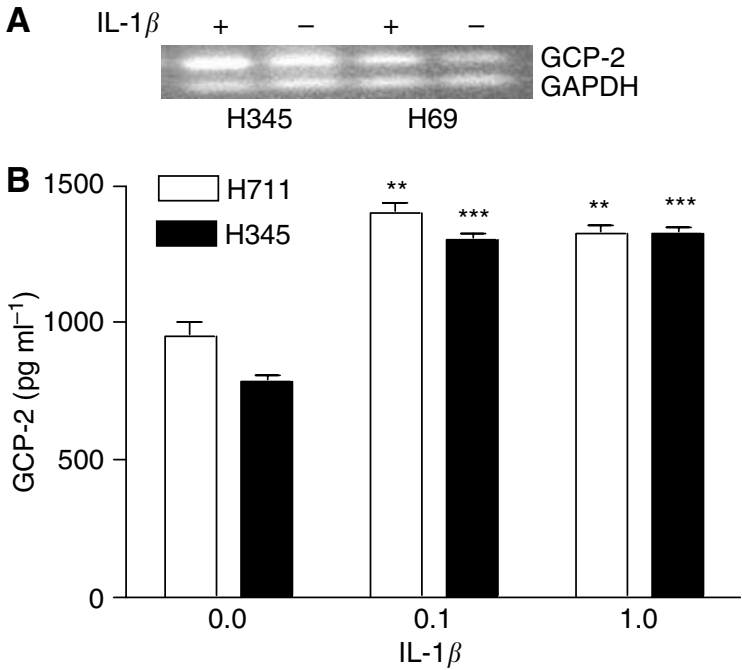

Figure 3 Upregulation of GCP-2 secretion by $|\mathrm{L}-| \beta$. (A) $|\mathrm{L}-| \beta$ upregulated GCP-2 mRNA detected by RT-PCR in both $\mathrm{H} 7 \mathrm{II}$ and $\mathrm{H} 345$ cell lines. (B) GCP-2 release was upregulated at $0.1 \mathrm{ng} \mathrm{ml}^{-1}$ in both H345 (84\% increase, $P<0.0 \mathrm{I}$ ) and $\mathrm{H} 7 \mathrm{II}$ ( $53 \%$ increase, $P<0.0 \mathrm{I}$ ) cell lines, and at I $\left.\mathrm{ng} \mathrm{ml}\right|^{-1}$ after $\mathrm{H} 345$ and $\mathrm{H} 7 \mathrm{I} \mid$ cells were treated by rlL-I $\beta$ for $24 \mathrm{~h}$. Each bar is the mean \pm s.e.m. of three determinations.
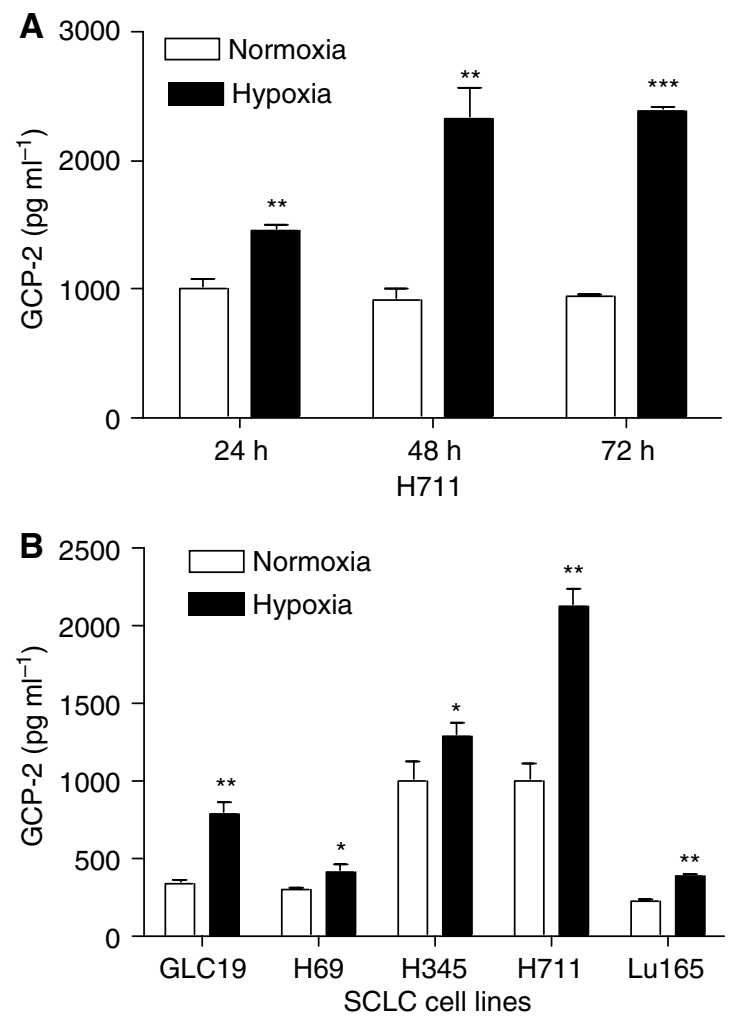

Figure 4 Upregulation of GCP-2 by hypoxia. (A) H7l I cells were cultured under normoxia and hypoxia $\left(0.5 \% \mathrm{O}_{2}\right)$ for 24,48 and $72 \mathrm{~h}$. Granulocyte chemotactic protein-2 measured by ELISA was significantly increased by $46 \%(P<0.0 \mathrm{I})$ at $24 \mathrm{~h}, \mathrm{I} 2 \mathrm{2} \%(P<0.0 \mathrm{I})$ at $48 \mathrm{~h}$ and $153 \%$ $(\mathrm{P}<0.00 \mathrm{l})$ at $72 \mathrm{~h}$. (B) The effects of $48 \mathrm{~h}$ hypoxia on GCP-2 production in a panel of SCLC cell lines. Granulocyte chemotactic protein-2 production measured by ELISA was significantly upregulated (range from 34\% in H69 to $129 \%$ increase in GLC19) in all tested SCLC cell lines. Each bar is the mean \pm s.e.m. of three determinations from two independent experiments.
$72 \mathrm{~h}$ (Figure 4A). GCP-2 was increased from between $1000 \pm 80$ $(24 \mathrm{~h})$ and $940 \pm 20 \quad(72 \mathrm{~h}) \mathrm{pg} \mathrm{ml}^{-1}$ under normoxia to $1460 \pm 40 \mathrm{pg} \mathrm{ml}^{-1}$ under hypoxia ( $46 \%$ increase, $P<0.01$ ) at $24 \mathrm{~h}$, to $2320 \pm 240 \mathrm{pg} \mathrm{ml}^{-1}(152 \%$ increase, $\left.P<0.01)\right)$ at $48 \mathrm{~h}$ and to $2380 \pm 40 \mathrm{pg} \mathrm{ml}^{-1}(153 \%$ increase, $P<0.001)$ at $72 \mathrm{~h}$. We further studied the effects of $48 \mathrm{~h}$ hypoxia on GCP-2 production in a panel of SCLC cell lines. Granulocyte chemotactic protein-2 production was significantly upregulated (range from $34 \%$ in $\mathrm{H} 69$ to $129 \%$ increase in GLC19) in all tested SCLC cell lines (Figure 4B).

Granulocyte chemotactic protein-2 is an autocrine mitogen for small cell lung cancer cells

Expression of the GCP-2 receptors CXCR1 and CXCR2 was studied by FACS. We found that all the SCLC cell lines express functional GCP-2 receptors (Figure 5). As SCLC cells express both GCP-2 and its receptors, we speculated that it could act as an autocrine growth factor for these cells. To test this, SCLC cells were treated with neutralising anti-GCP-2 antibody for $48 \mathrm{~h}$. As measured by MTT assay, cell proliferation was significantly inhibited by $26 \%$ $(P<0.01)$ in $\mathrm{H} 711$ and by $21 \%(P<0.05)$ in $\mathrm{H} 345$, but cell lines GLC-19, H69 and Lu165 were not significantly affected (Figure 6A). We also studied the effects of exogenous GCP-2 on cell proliferation by examining the expression of the proliferation marker, proliferating cell nuclear antigen (PCNA) by flow cytometry with mouse anti-human PCNA monoclonal antibody and control mouse IgG2a antibody. The results are expressed as the mean fluorescent intensity. Recombinant GCP-2 (0.1-
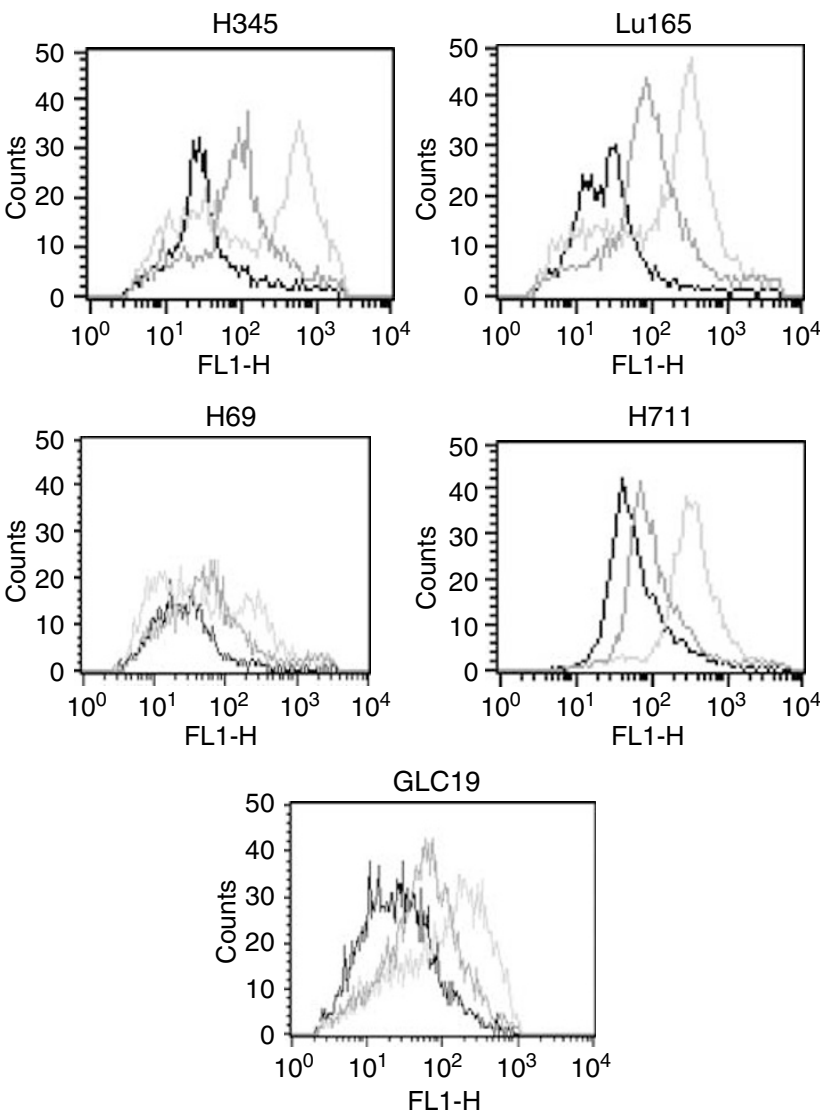

Figure 5 Expression of CXCRI and CXCR2 on SCLC cells. Expression of the CXCRI and CXCR2 was detected by FACS in a panel of SCLC cell lines. All the SCLC cell lines express functional GCP-2 receptors. Expression of CXCRI (right histogram) were higher than CXCR2 (middle histogram) in all SCLC cell lines. 

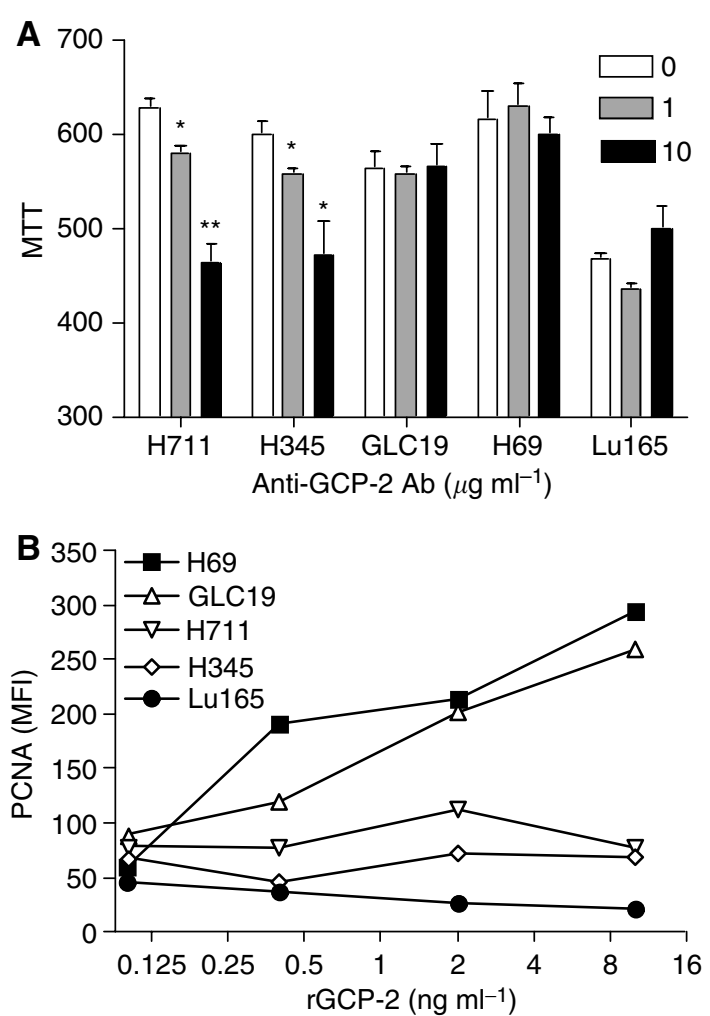

Figure 6 Granulocyte chemotactic protein-2 is an autocrine mitogen for SCLC cells. (A) After SCLC cells were treated with neutralising anti-GCP-2 antibody for $48 \mathrm{~h}$, cell proliferation was significantly inhibited by $26 \%$ $(P<0.0 \mathrm{I})$ in $\mathrm{H} 7 \mathrm{II}$ and by $21 \%(P<0.05)$ in $\mathrm{H} 345$, but not affected in $\mathrm{H} 69$, GLCI9 and Lul65. Each bar is the mean \pm s.e.m. of three determinations from two independent experiments. (B) The expression of PCNA was measured by flow cytometry following the treatment of exogenous GCP-2. The results are expressed as the mean fluorescent intensity. rGCP-2 (0.I $10 \mathrm{ngll}^{-1}$ ) upregulated the expression of PCNA in dose-dependent manner in two low-GCP-2-producing cell lines H69 and GLC19. In contrast, expression of PCNA was not increased after rGCP-2 treatment in high-GCP-2-producing cell lines H7II and H345, or in Lul65.

$10 \mathrm{ng} \mathrm{ml}^{-1}$ ) upregulated the expression of PCNA in a dosedependent fashion in two low-GCP-2-producing cell lines H69 and GLC19. Expression of PCNA increased five-fold in H69 and three-fold in GLC-19 cells when the cells were treated with rGCP-2 at a final concentration of $10 \mathrm{ng} \mathrm{ml}^{-1}$ (Figure 6B). In contrast, expression of PCNA was no significantly increased after rGCP-2 treatment in the two high-GCP-2-producing cell lines, H711 and $\mathrm{H} 345$, or in Lu165.

\section{DISCUSSION}

Granulocyte chemotactic protein-2 was originally isolated from conditioned medium of osteosarcoma cells (Proost et al, 1993). Subsequent studies have shown that GCP-2 was produced in tumour cell lines such as MG-63, HeLa, and Bowes. It has been shown to have mitogenic and angiogenic properties in different models (Strieter et al, 1995; Van Coillie et al, 2001). Like other ELR + CXC chemokines, GCP-2 was chemotactic to endothelial cells in vitro and promoted rat cornea neovascularization in vivo (Strieter et al, 1995). Van Coillie et al (2001) showed that tumourderived GCP-2 increased angiogenesis through activation of tumour-associated neutrophils and intratumoral expression of gelatinase B. GCP-2 binds to both CXCR1 and CXCR2 with similar high affinity. Both receptors are G protein-coupled seventransmembrane domain receptors, but different biological functions may be mediated by the different receptors. CXCR1 is believed to mediate the chemotactic activity, whereas CXCR2 mediates the angiogenic activity of CXC ELR + chemokines such as IL-8 (Heidemann et al, 2003; Ramjeesingh et al, 2003; Bates et al, 2004).

Angiogenesis and metastasis are essential to tumour development. Angiogenic factors have been extensively described in NSCLC but not in SCLC. Expression of VEGF was detected in 43 of $54(81 \%)$ patients with SCLC, but was not associated with survival (Dowell et al, 2004) although increased expression of VEGF in SCLC was associated with poorer prognosis in another indepedent study (Fontanini et al, 2002). To date SCLC cells have been found to produce lower levels than NSCLC of pro-angiogenic factors such as VEGF and IL-8 (Yatsunami et al, 1997). This suggests that SCLC might utilise different angiogenic factors than NSCLC. In this study, we report that SCLC cells secrete GCP-2, whereas NSCLC cells do not, as shown by ELISA of conditioned media in cell culture, Western blotting of cell lysates and immunohistochemistry of tumour specimens. This finding demonstrates that SCLC cells secrete an additional pro-angiogenic factor to NSCLC. We therefore further studied the regulation and function of GCP-2 in SCLC.

We investigated the role of NF- $\kappa \mathrm{B}$ (p65), a crucial transcription factor that mediates chemokine induction, in GCP-2 secretion by exposing cells to ALLN, which stabilises I $\kappa$ B. ALLN almost completely abolished GCP-2 secretion in H345 and H711 cells, suggesting that NF- $\kappa \mathrm{B}$ is a major regulator of GCP-2 expression in SCLC. We further tested whether IL-1 $\beta$ upregulated GCP-2 in SCLC cells. Both mRNA and protein of GCP-2 were significantly increased in two SCLC cell line tested. This result suggests that upregulation of GCP- 2 by IL- $1 \beta$ is initiated at the transcriptional level. IL- $1 \beta$ has been found to induce NF- $\kappa$ B activation in cancer cells such as leukaemic cell line OCIM2 (Estrov et al, 1999). Therefore, upregulation of GCP-2 by IL- $1 \beta$ may be mediated by $\mathrm{NF}-\kappa \mathrm{B}$ induction.

Granulocyte chemotactic protein-2 is one of the CXC ELR + chemokines with pro-angiogenic properties. GCP-2 has previously been shown to act as an angiogenic factor (Strieter et al, 1995). Many angiogenic factors are induced when tumour cells are exposed to unfavourable conditions such as hypoxia. We therefore investigated the role of hypoxia on GCP-2 production in SCLC cells. We found that GCP-2 was significantly increased in all SCLC cell lines after $48 \mathrm{~h}$ in $0.5 \% \mathrm{O}_{2}$. Among them, GCP-2 production was increased by over $120 \%$ in H711 and GLC19 cell lines. The underlying mechanism of upregulation of GCP-2 by hypoxia in SCLC has not yet been defined. We scrutinised the promoter region of GCP-2 (Mine et al, 2003), and found a potential hypoxiainducable factor (HIF) DNA binding site (GCGTG) (Wenger and Gassmann, 1997) present in the hypoxia-response element (HRE) from -430 to -424 within the promoter of GCP-2. It has been well documented that HIF is rapidly stabilised upon exposure to hypoxia (Wenger, 2000). Therefore, HIF may mediate GCP-2 upregulation by hypoxia in SCLC cells. In addition to HIF, NF- $\kappa \mathrm{B}$ may play a role in the upregulation of GCP-2 by hypoxia. Hypoxia can upregulate genes without an HRE in their promoters and such hypoxia-induced gene induction was NF- $\kappa \mathrm{B}$-dependent (Karashima et al, 2003). The mechanism of GCP-2 upregulation by hypoxia merits further study.

As SCLC cells expressed CXCR1 and CXCR2 on the cell membrane and secrete GCP-2, we further investigated the biological functions of GCP-2 in SCLC in this study. Expression of PCNA, a marker of cell proliferation, was significantly increased after SCLC cells were treated with rGCP-2 in at least two low GCP2-producing cell lines GLC19 and H69. Cell proliferation was inhibited after the cells were treated with neutralising anti-GCP-2 antibody in two high-GCP-2-producing cell lines (H711 and H345), 
but not in three low-GCP-2-producing cell lines GLC19, H69 and Lu165. These results suggest that GCP-2 may act as an autocrine growth factor in SCLC cells. Interleukin-8 (IL-8), which shares the CXCR1 and CXCR2 receptors with GCP-2, was also found to be mitogenic to SCLC (Zhu et al, 2004). The signal transduction pathways mediating the mitogenic function of IL-8 are complex, include extracellular signal-regulated kinase (ERK) of mitogenactivated protein kinase (MAPK) pathway, NF- $\kappa \mathrm{B}$, and epidermal growth factor receptor (EGFR) pathway by cross-talk (Zhu and Woll, 2005). As the GCP-2 binds to the same receptors, we speculate that the same pathways will be utilised.

In summary, we showed that SCLC cells constitutively secrete GCP-2 chemokine but NSCLC cells do not. GCP-2 production can be significantly upregulated by IL-1 $\beta$ and hypoxia. Granulocyte

\section{REFERENCES}

Balkwill F (2004) The significance of cancer cell expression of the chemokine receptor CXCR4. Semin Cancer Biol 14: 171-179, doi:10.1016/j.semcancer.2003.10.003

Bates RC, DeLeo III MJ, Mercurio AM (2004) The epithelial-mesenchymal transition of colon carcinoma involves expression of IL-8 and CXCR-1mediated chemotaxis. Exp Cell Res 299: 315-324, doi:10.1016/ j.yexcr.2004.05.033

Chen JJ, Yao PL, Yuan A, Hong TM, Shun CT, Kuo ML, Lee YC, Yang PC (2003) Up-regulation of tumor interleukin-8 expression by infiltrating macrophages: its correlation with tumor angiogenesis and patient survival in non-small cell lung cancer. Clin Cancer Res 9: 729-737

Cox G, Jones JL, Walker RA, Steward WP, O’Byrne KJ (2000) Angiogenesis and non-small cell lung cancer. Lung Cancer 27: 81 -100, doi:10.1016/ S0169-5002(99)00096-3

Dowell JE, Amirkhan RH, Lai WS, Frawley WH, Minna JD (2004) Survival in small cell lung cancer is independent of tumor expression of VEGF and COX-2. Anticancer Res 24: 2367-2373

Estrov Z, Manna SK, Harris D, Van Q, Estey EH, Kantarjian HM, Talpaz M, Aggarwal BB (1999) Phenylarsine oxide blocks interleukin-1beta-induced activation of the nuclear transcription factor NF-kappaB, inhibits proliferation, and induces apoptosis of acute myelogenous leukemia cells. Blood 94: $2844-2853$

Fontanini G, Faviana P, Lucchi M, Boldrini L, Mussi A, Camacci T, Mariani MA, Angeletti CA, Basolo F, Pingitore R (2002) A high vascular count and overexpression of vascular endothelial growth factor are associated with unfavourable prognosis in operated small cell lung carcinoma. $\mathrm{Br} J$ Cancer 86: $558-563$, doi:10.1038/sj.bjc.6600130

Gijsbers K, Gouwy M, Struyf S, Wuyts A, Proost P, Opdenakker G, Penninckx F, Ectors N, Geboes K, Van Damme J (2005) GCP-2/CXCL6 synergizes with other endothelial cell-derived chemokines in neutrophil mobilization and is associated with angiogenesis in gastrointestinal tumors. Exp Cell Res 303: 331 -342, doi:10.1016/j.yexcr.2004.09.027

Heidemann J, Ogawa H, Dwinell MB, Rafiee P, Maaser C, Gockel HR, Otterson MF, Ota DM, Lugering N, Domschke W, Binion DG (2003) Angiogenic effects of interleukin 8 (CXCL8) in human intestinal microvascular endothelial cells are mediated by CXCR2. J Biol Chem 278: 8508 - 8515, doi:10.1074/jbc.M208231200

Karashima T, Sweeney P, Kamat A, Huang S, Kim SJ, Bar-Eli M, McConkey DJ, Dinney CP (2003) Nuclear factor-kappaB mediates angiogenesis and metastasis of human bladder cancer through the regulation of interleukin-8. Clin Cancer Res 9: 2786-2797

Mine S, Nasu K, Fukuda J, Sun B, Miyakawa I (2003) Secretion of granulocyte chemotactic protein-2 by cultured human endometrial stromal cells. Fertil Steril 79: 146-150, doi:10.1016/S00150282(02)04552-1

Proost P, De Wolf-Peeters C, Conings R, Opdenakker G, Billiau A, Van Damme J (1993) Identification of a novel granulocyte chemotactic protein (GCP-2) from human tumor cells. In vitro and in vivo chemotactic protein-2 production is mediated by NF- $\kappa \mathrm{B}$. In addition to its angiogenic property previously shown in other studies, we demonstrated that GCP-2 can act as an autocrine growth factor to most SCLC cells. Thus, GCP-2 could be critical to the tumour development in SCLC. These results suggest that targeting GCP-2 may inhibit tumour growth in SCLC.

\section{ACKNOWLEDGEMENTS}

We thank Professor Claire Lewis for help with the hypoxia studies. This work was supported by Weston Park Hospital Cancer Appeal and Yorkshire Cancer Research. comparison with natural forms of GRO, IP-10, and IL-8. J Immunol 150: $1000-1010$

Ramjeesingh R, Leung R, Siu CH (2003) Interleukin-8 secreted by endothelial cells induces chemotaxis of melanoma cells through the chemokine receptor CXCR1. FASEB J 17: $1292-1294$, doi: 10.1096/ fj.02-0560fje

Rovai LE, Herschman HR, Smith JB (1997) Cloning and characterization of the human granulocyte chemotactic protein-2 gene. J Immunol 158: $5257-5266$

Strieter RM, Polverini PJ, Kunkel SL, Arenberg DA, Burdick MD, Kasper J, Dzuiba J, Van Damme J, Walz A, Marriott D, Chan S-Y, Roczniak S, Shanafelt AB (1995) The functional role of the ELR motif in CXC chemokine-mediated angiogenesis. J Biol Chem 270: 27348-27357

Van Coillie E, Van Aelst I, Wuyts A, Vercauteren R, Devos R, De WolfPeeters C, Van Damme J, Opdenakker G (2001) Tumor angiogenesis induced by granulocyte chemotactic protein-2 as a countercurrent principle. Am J Pathol 159: 1405-1414

Wenger RH (2000) Mammalian oxygen sensing, signalling and gene regulation. J Exp Biol 203: 1253-1263

Wenger RH, Gassmann M (1997) Oxygen(es) and the hypoxia-inducible factor-1. Biol Chem 378: 609-616

Wuyts A, Struyf S, Gijsbers K, Schutyser E, Put W, Conings R, Lenaerts JP, Geboes K, Opdenakker G, Menten P, Proost P, Van Damme J (2003) The CXC chemokine GCP-2/CXCL6 is predominantly induced in mesenchymal cells by interleukin- $1 \beta$ and is down-regulated by interferon- $\gamma$ : comparison with interleukin-8/CXCL8. Lab Invest 83: 23-34, doi:10.1097/01.LAB.0000048719.53282.00

Yatsunami J, Tsuruta N, Ogata K, Wakamatsu K, Takayama K, Kawasaki M, Nakanishi Y, Hara N, Hayashi S (1997) Interleukin-8 participates in angiogenesis in non-small cell, but not small cell carcinoma of the lung. Cancer Lett 120: 101 - 108, doi:10.1016/S0304-3835(97)00296-6

Yuan A, Yang PC, Yu CJ, Chen WJ, Lin FY, Kuo SH, Luh KT (2000) Interleukin-8 messenger ribonucleic acid expression correlates with tumor progression, tumor angiogenesis, patient survival, and timing of relapse in non-small-cell lung cancer. Am J Respir Crit Care Med 162: $1957-1963$

Zhu YM, Bradbury DA, Pang L, Knox AJ (2003) Transcriptional regulation of interleukin (IL)-8 by bradykinin in human airway smooth muscle cells involves prostanoid-dependent activation of AP-1 and nuclear factor (NF)-IL-6 and prostanoid-independent activation of NF-kappaB. J Biol Chem 278: 29366-29375, doi:10.1074/jbc.M301785200

Zhu YM, Webster SJ, Flower D, Woll PJ (2004) Interleukin-8/CXCL8 is a growth factor for human lung cancer cells. Br J Cancer 91: 1970 - 1976, doi:10.1038/sj.bjc.6602227

Zhu YM, Woll PJ (2005) Mitogenic effects of interleukin-8/CXCL8 on cancer cells. Future Oncol 1: 699-704, doi:10.2217/14796694.1.5.699.2005

Zlotnik A (2004) Chemokines in neoplastic progression. Semin Cancer Biol 14: 181 - 185, doi:10.1016/j.semcancer.2003.10.004 